arsenoxide also differs from others in its mode of fixation on the trypanosome cell, but not in the essential mechanism of its lethal effect.

The obvious type of compound in which to seek for the property of selective interference with 'Melarsen oxide' would be a substance containing the melamine nucleus. Such a compound is 'Surfen C', bis(2 - methyl - 4 - amino - 6 - quinolyl) melamine [III], which is itself a chemotherapeutic agent of significant activity against $T$. congolense and $T$. bruce $i^{10}$. It also exercises some action on our strain of $T$. rhodesiense. In the experiments below, mice were infected with the parent strain of $T$. rhodesiense and treated under the standard conditions of timing and degree of infection mentioned above; in these circumstances more than 24 hours elapse before the blood becomes free of trypanosomes after treatment with 'Surfen C' even in maximal doses.

Table 2 gives the results of a number of interference experiments and shows that while $p$-aminobenzoic acid interferes selectively with Eagle's compound, 'Surfen C' interferes similarly with 'Melarsen oxide'.

TABLE 2. SEI.EOTIVI INTERPERENOE : $p$-AMINOBENZOIC AOID AGATNST $\gamma$-(p-ARSENOSOPHENYL)BUTYRIO AOD (EAGLE'S COMPOUND), AND 'SURFEN C' AGAINST' 'MELARSEN OXIDE'

\begin{tabular}{|c|c|c|c|}
\hline \multirow{2}{*}{$\begin{array}{c}\text { Treated with } \\
\text { (intraperitoneally) }\end{array}$} & \multicolumn{3}{|c|}{ Main treatment preceded $5 \mathrm{~min}$. by } \\
\hline & - & $\begin{array}{c}p \text {-Aminobenzoic } \\
\text { acid } \\
(70 \mathrm{mgm} . / 20 \mathrm{gm} .)\end{array}$ & $\begin{array}{c}\text { 'Surfen C' } \\
\text { (4 mgm./20 gm.) }\end{array}$ \\
\hline $\begin{array}{l}\text { 'Mapharside' } \\
0.015 \text { mgm./20 gm.* } \\
\text { Eagle's compound } \\
0.015 \text { mgm./20 gm." } \\
\text { 'Melarsen oxide' } \\
0.003 \text { mgm. } / 20 \text { gm." }\end{array}$ & $\begin{array}{l}\text { cl } \\
\text { el } \\
\text { el }\end{array}$ & $\begin{array}{l}\text { cl } \\
\mathrm{n} \\
\mathrm{el}\end{array}$ & $\begin{array}{l}\text { cl } \\
\text { cl } \\
\mathrm{n}\end{array}$ \\
\hline
\end{tabular}

Fach cell of the table represents results of treating at least eight mice. $\mathrm{ED}_{95}$, that is, dose causing temporary disappearance of trypanosomes from the blood in 95 per cent of mice (estimated by probit analysis of numerous trials).

$\mathrm{cl}=$ blood cleared of trypanosomes in 24 hours.

$\mathrm{n}=$ blood not cleared of trypanosomes in 24 hours.

Other tests showed that glutathione interferes equally with the action of 'Melarsen oxide' and of the other arsenoxides. If, then, glutathione interference be accepted as evidence that the essential mechanism of lethal action is by interference with - SH constituents of the parasite cell ${ }^{11}$, we may conclude that 'Melarsen oxide' (like Eagle's compound) shares this mode of action with other arsenoxides, but that it differs in its fixation on, or route of entry into, the trypanosome, this fixation or route being selectively blocked by 'Surfen C'.

It is reasonable to suppose that it is the melamine nucleus of 'Surfen C' which determines the selective nature of its interference with 'Melarsen oxide'. If this were so, then no such selective interference should be exercised by 'Surfen' [IV], which differs from 'Surfen C' by having a carbamide instead of a melamine linkage between the two quinoline systems ${ }^{10}$. This anticipation was substantiated by interference experiments in respect of 'Surfen' and the three arsenoxides. It was found, however, by examining the blood at hourly intervals within eight hours of treatment, that instead of complete absence of any interference with the three arsenicals (as found in similar tests of 'Surfen C' with 'Mapharside' and Eagle's compound, respectively), 'Surfen' does exercise some degree of interference with each of the three arsenicals. The significance of this non-specific interference will be elaborated elsewhere, but mean. while it is established that the interference of 'Surfen C' operates selectively against 'Melarsen oxide', and presumably depends on the presence of the melamine system in both compounds*.

The facts, therefore, warrant the view that while the ultimate lethal mechanism of 'Melarsen oxide' is the same as that of other arsenoxides (by inactivation of - $\mathrm{SH}$ groups, perhaps of the pyruvate oxidase system $^{12}$ ), it has a radically different means of fixation on, or entry into, the trypanosome cell, and it is this difference which may underlie the fact that it is active against trypanosomes resistant to the more usual type of arsenical. We have recently reached a similar conclusion in connexion with antimalarials. Representatives of the earlier pyrimidine prototypes of 'Paludrine', such as $3349^{13}$, are active against 'Paludrine'-resistant $P$. gallinaceum, and we have connected this finding with the conception that the pyrimidine precursors of 'Paludrine' share with the latter a common (but unknown) ultimate mode of lethal action on the malaria parasite, while differing in their mechanisms of attachment to, or entry into, the parasite cell ${ }^{14}$.

This work was supported by grants from the Medical Research Council. We are obliged to Messrs. Parke Davis and Co. for supplies of 'Melarsen' and 'Melarsen oxide'.

* Note added in proof. This supposition has been further supported by finding that melamine itself interferes with the therapeutic action of 'Melarsen oxide', but not of 'Mapharside' or Eagle's compound.

1 Friedheim, E. A. H., Ann. Inst. Past., 65, 108 (1940).

${ }^{2}$ Friedheim, E. A. H., J. Amer. Chem. Soc., 66, 1775 (1944).

' Weinman, D., and Franz, K., Amer. J. Trop. Med., 25, 343 (1945)。

"Van Hoof, L., Trans, Roy. Soc. Trop. Med. Hyg., 40, 727 (1947).

${ }^{5}$ Yorke, W., and Murgatroyd, F., Ann. Trop. Med. Parasitol., 24, 449 (1930).

B Ehrlich, P., Areh. f. Schiffs.-u. Trop. Hyg., 13 Bhft., 321 (1909),

' King, H., and Strangeways, W., Ann. Trop. Med. Parasitol., 36, $47(1942)$.

${ }^{8}$ Eagle, H., Science, 101, 69 (1945)

- Williamson, J., and Lourie, E. M., Ann. Trop. Med. Parasitol., 40, 255 (1946).

${ }^{10}$ Iensch, H., Ang. Chem., 50, 891 (1937).

11 Voegtlin, C., Dyer, H. A., and Leonard, C. S., Pub. Health Rep. Wash, 38, 1882 (1923).

12 Peters, R. A., Stocken, I. A., and Thompson, R. H. S., Nature, 156, 616 (1945).

${ }^{13}$ Curd, F. H. S., Davey, D. G., and Rose, F. L., Ann. Trop. Med. Parasitol., 39, 157 (1945).

1s Williamson, J., and Lourie, E. M., Ann. Trop. Med. Parasitol. 41, 278 (1947).

\section{INTERNATIONAL STUDY OF RHEOLOGY}

\section{International Joint Committee on Rheology}

TN December 1945 the International Council of 1 Scientific Unions instituted a Joint Committee on Rheology, with representatives of the International Unions for Physics, Chemistry, Biological Sciences, and Geodesy and Geophysics, to which afterwards was added the International Union for Theoretical and Applied Mechanics. The International Union of Physics will act as 'mother union' for this Committee.

The Committee held its first meeting during September 8-9, 1947, in London. It was decided that its terms of reference should be to co-ordinate research and to investigate problems concerning the deformation and the flow of matter, and the following were nominated as officers for the year 1947-48: Chairman, Dr. Th. von Karman, Pasadena, Cal. ; Vice. chairman, Mme. A. Dobry-Duclaux, Paris ; Secretary, 
Dr. J. M. Burgers (van Houtenstraat 1, Delft, Holland); Committee, P. Eggleton, H. Eyring, A. Frey-Wyssling, G. van Iterson, jun., G. W. Scott Blair, R. Signer and Sir Geoffrey Taylor. The Committee intends to act as a central body for establishing contact between scientific men and societies engaged upon work in rheology. For this purpose it has chosen the following subjects for its initial activities: nomenclature; abstracting work in rheology; standards of high viscosity. A report on the nomenclature of deformations, prepared in Holland during the War under the auspices of the Committee for the Study of Viscosity and Plasticity of the Royal Netherlands Academy of Sciences (Amsterdam), was considered at the meeting. This report, after modification as a result of discussion, will be submitted both to the members of the Committee and to co-operating societies and groups, with an invitation to send in criticisms and, if desired, new proposals.

As regards abstracting work in rheology, a report will be prepared on what is already being done in this subject, and contact will be established with the United Nations Educational, Scientific and Cultural Organisation. Finally, information will be collected on materials suitable as standards of viscosity of the order of $10^{6}$ poise and more.

\section{International Rheological Congress}

An International Rheological Congress will be organised by a Dutch committee, to be held in Scheveningen (near The Hague), during September 21-25, 1948. The Joint Committee intends to hold a meeting during this Congress, at which the information gathered can be discussed and eventually brought before the Congress. The provisional programme includes the following topics: recent developments in the theory of viscosity; nomenclature ; fundamental experimental methods; solutions of macromolecular substances; Russian work on rheology; relations between stress and strain in complicated systems; abnormal substances and abnormal phenomena of flow; psycho-physical aspects of rheology ; rheological problems in biology ; rheology in industry.

An agreement has been reached with the Elsevier Publishing Company, Inc., of Amsterdam, to publish the Proceedings of the Congress in book form. Preprints of all papers will be forwarded to participants at least a month in advance of the Congress. Remarks in discussion will be included in the final edition of the Proceedings. Those intending to present papers should communicate with the principal secretary, Dr. R. Houwink, Rubber-Stichting, Julianalaan 134, Delft, Holland. Manuscripts must be received before May 1, 1948. A maximum of 3,000 words, formulæ and diagrams included, should not be exceeded, and the organising committee must, in consequence of present restrictions, reserve the right to cut down papers.

It is proposed that in the sectional meetings every speaker will give only a short account of his paper or mention the most important points, so that ample time will be available for discussion. The time to be allotted to each paper, inclusive of discussion, will be at most thirty minutes, but may perhaps have to be reduced if many papers are presented.

Due to generous support from Dutch industry and from some Dutch scientific societies, it will be possible to fix the Congress fee for participants at approximately f. $10(£ 1)$, which it is hoped will also cover the cost of the preprints. It does not, however, include the price of the final edition of the Proceedings, which can be fixed only when all papers have been received. The organising committee will assist in obtaining accommodation at Schevingen.

The members of the organising committee are : J. M. Burgers (Chairman), R. Houwink (Principal Secretary), H. Kramers, A. J. Staverman, R. N. J. Saal, A. van Rossem, H. C. den Daas.

\section{RESULTS OF THE CONTINUOUS USE OF AN AMMONIUM PHOSPHATE FERTILIZER ON RICE IN LOWER BURMA}

\author{
By D. RHIND, O.B.E., and U TIN \\ Dept. of Agriculture, Burma
}

CULTIVATORS in parts of the Irrawaddy delta 1 complained that after a few years use of an ammonium phosphate fertilizer on rice lands, they had continually to increase the dose in order to obtain the same response. An experiment was devised to test this opinion ${ }^{1,2}$.

A proprietory ammonium phosphate fertilizer, the one complained of, was applied repeatedly for eleven years to a series of plots replicated five times on Myaungmya Farm in the Irrawaddy delta. The experiment continued from 1930 until 1940 inclusive, when it was interrupted by the War. The soil is a recent, acid alluvium; the rainfall averaged $93 \cdot 14$ in. a year during the period of the experiment; the variety of rice was the pure line Ngasein C14-8. The soil analysis is given in Table 1 .

TABLE 1. MYAUNGMYA FARM SOIL

Insoluble residue
Soluble silica
Ferric oxide $\left(\mathrm{Fe}_{2} \mathrm{O}_{8}\right)$
Alumina $\left(\mathrm{Al}_{2} \mathrm{O}_{8}\right)$
Lime (CaO)
Magnesia $\left(\mathrm{MgO}^{\circ}\right)$
Potash $\left(\mathrm{K}_{2} \mathrm{O}\right)$
Soda $\left(\mathrm{Na}_{2} \mathrm{O}\right)$
Sulphuric acid $\left(\mathrm{SO}_{8}\right)$
Phosphoric acid $\left(\mathrm{P}_{2} \mathrm{O}_{5}\right)$
Carbon dioxide
Organic matter-combined water
Moisture lost at $100^{\circ} \mathrm{C}$
Manganese oxide $\left(\mathrm{Mn}_{3} \mathrm{O}_{4}\right)$
Organic carbon
Organic nitrogen
Available $\mathrm{P}_{2} \mathrm{O}_{5}$
Available potash
pH

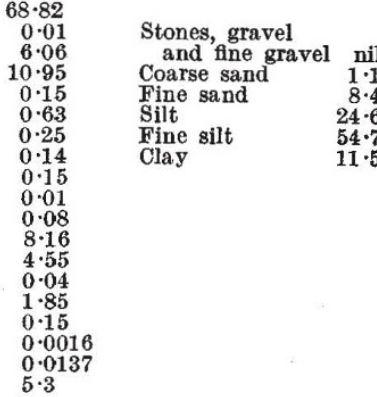

The fertilizer contained $18 \cdot 20$ per cent of nitrogen and 18.43 per cent of $\mathrm{P}_{2} \mathrm{O}_{5}$, and was applied at the rate of $100 \mathrm{lb}$. per acre shortly before transplanting. Cultivation methods were those normal to the area, seedlings being raised in unmanured nurseries and transplanted. Rice in the Irrawaddy delta is grown continuously without rotation as a single monsoon crop.

In every year the yields of the manured plots were significantly higher than the unmanured, and this is the normal effect of ammonium phosphate fertilizers on soils of this type. The point which the following analysis brings out, and which is important, is that after the first few years there was a decline in the response to the fertilizer, though at the end of the experiment there was still a significant increment over the unmanured plots. 